\title{
Rolling Stability Control Utilizing Rollover Index for In-wheel Motor Electric Vehicle
}

\author{
Kiyotaka Kawashima Student Member (The University of Tokyo, kawashima@horilab.iis.u-tokyo.ac.jp) \\ Toshiyuki Uchida Non-member (The University of Tokyo, uchida@horilab.iis.u-tokyo.ac.jp) \\ Yoichi Hori Senior Member (The University of Tokyo, hori@iis.u-tokyo.ac.jp)
}

Keywords: rolling stability control, electric vehicle, disturbance observer, two-degrees-of-freedom control, vehicle motion control

In this paper, a novel integrated stability program (ISP) based on robust rolling stability control (RSC) for in-wheel motor electric vehicle (EV) is proposed. Since EVs are driven by electric motors, they have the following four remarkable advantages: (1) motor torque generation is quick and accurate; (2) motor torque can be precisely estimated; (3) a motor can be attached to each wheel; and (4) a motor can output negative torque as a brake actuator. These advantages enable a high-performance three-dimensional vehicle motion control with a distributed in-wheel-motor system.

In this study, RSC is designed by using two-degree-of-freedom (2-DOF) control, which achieves tracking capability to the reference value and disturbance suppression. Lateral acceleration disturbance $\hat{a}_{y d}$ is estimated by disturbance observer (DOB) using steering sensor $\delta$, lateral acceleration $a_{y}$, and differential torque $N$. The following equation expresses that disturbance, which is lower than the cut-off frequency of $Q$, is suppressed by DOB.

$$
a_{y}=v+P_{a_{y} \delta}^{n} \delta+(1-Q) \hat{a}_{y d} .
$$

Fig. 1 shows the experimental results of RSC. Under a constant velocity control of $6.0 \mathrm{~m} / \mathrm{s}$, Fig. 1(a) shows disturbance roll moment suppression and (b) shows tracking capability to the reference value,

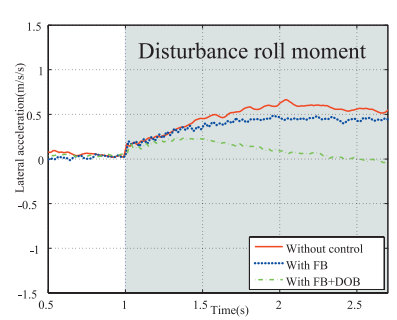

(a) Disturbance suppression

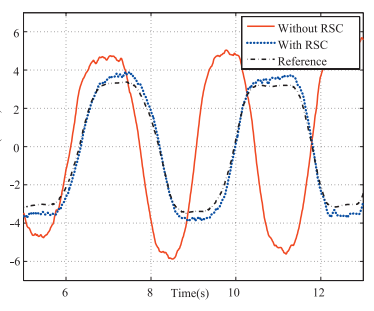

(b) Tracking capability to the reference value
Fig. 1. Experimental result of RSC which is $80 \%$ of the nominal value.

On the other hand, if the constant vehicle speed is assumed and lateral acceleration is suppressed, the yaw rate is also suppressed as long as the differentiation of side slip is not controlled. This physical constraint makes RSC and yaw stability control (YSC) incompatible. Therefore, variable weight-ISP (VW-ISP) and variable reference-ISP (VR-ISP) are proposed using rolling state information. In order to detect rollover, advanced rollover index $R I$ $(0<R I<1)$ is introduced. For VW-ISP, when $R I$ is high, which means a vehicle is likely to roll over, the weight of RSC is set as high. On the other hand, when $R I$ is small, which means a vehicle is not likely to roll over, the weight of YSC is set as high. However, steady state error exists because integral control is not applicable for VW-ISP. Therefore, VR-ISP, which varies the reference value of RSC by $R I$, is also proposed to decrease steady state error.

Fig. 2(a) shows the comparison of RSC and VW-ISP. In the case of RSC, lateral acceleration is strongly suppressed. On the other hand, in the case of VW-ISP, yaw rate at steady state is recovered close to the reference value. Fig. 2(b) shows the comparison of VWISP and VR-ISP. Steady state error exists in the case of VW-ISP, whereas steady state error is almost zero in the case of VR-ISP.

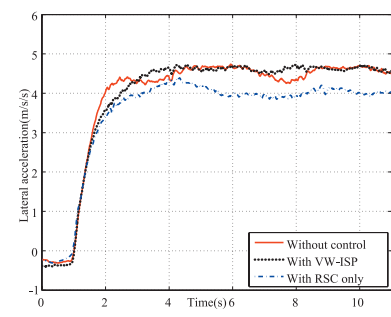

(a) Variable weight type

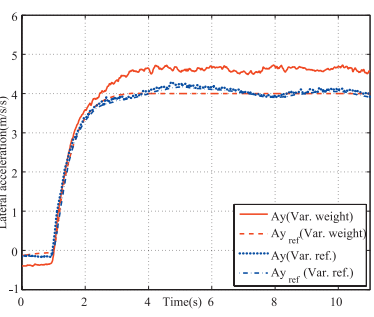

(b) Variable reference type
Fig. 2. Experimental result of ISP 


\title{
ロールオーバ指標を用いたインホイールモータ搭載 電気自動車におけるロール安定化制御
}

\author{
学 生員 河島 清貴* 非会員 内田 利之* \\ 上級会員 堀 洋一**
}

\section{Rolling Stability Control Utilizing Rollover Index for In-wheel Motor Electric Vehicle}

Kiyotaka Kawashima*, Student Member, Toshiyuki Uchida*, Non-member, Yoichi Hori**, Senior Member

In this paper, a novel integrated stability program (ISP) based on robust rolling stability control (RSC) for in-wheel electric vehicle $(\mathrm{EV})$ is proposed. Since EVs are driven by electric motors, they have the following four remarkable advantages: (1) motor torque generation is quick and accurate, (2) motor torque can be estimated precisely, (3) a motor can be attached to each wheel, and (4) a motor can output negative torque as a brake actuator. These advantages enable a high-performance three-dimensional vehicle motion control with a distributed in-wheel-motor system. Rolling stability is important for all classes of light-vehicles, especially, for EVs that have narrow tread and high center of gravity. In this study, RSC is designed using two-degree-of-freedom control (2-DOF), which achieves tracking capability to reference value and disturbance suppression. However, as the drivability of the vehicle will be changed significantly if only RSC is applied, vehicle rolling motion should be controlled depending on the rolling state. Therefore, variable weight-ISP and variable reference-ISP are proposed using rolling state information. For detecting rolling state, rollover index $(R I)$ is introduced. The validity of the proposed methods is shown by the simulation and the experimental results.

キーワード：ロール安定化制御，電気自動車，外乱オブザーバ，二自由度制御，車両運動制御

Keywords: rolling stability control, electric vehicle, disturbance observer, two-degrees-of-freedom control, vehicle motion control

\section{1. はじめに}

電気自動車 $(\mathrm{EV})$ はエンジン車に比べて燃費面で優れて いるだけなく, 電気モータの高い制御性を利用することで高 性能な車体姿勢制御が可能となる。本論文ではインホイー ルモー夕搭載 EV (IMEV) における外乱にロバストなロー ル安定化制御（Rolling stability control：RSC）と，ロール オーバ指標を用いたRSC とヨー運動制御（Yawing stability control：YSC）の統合制御（Integrated stability program : ISP）を提案する。

〈1・1〉インホイールモータを搭載した電気自動車の利 点 インホイールモータを搭載した EV は以下のような 利点を持っている(1) :

\footnotetext{
* 東京大学工学系研究科電気工学専攻

干 113-8654 東京都文京区本郷 7-3-1

Department of Electrical Engineering, The University of Tokyo

7-3-1, Hongo, Bunkyo-ku, Tokyo 113-8656

** 東京大学大学院新領域創成科学研究科先端エネルギー工学専攻

₹ 277-8561 柏市柏の葉 5-1-5 新領域基盤棟 7E1

Graduate School of Frontier Sciences, The University of Tokyo

7E1 Transdisciplinary Sciences Bldg., 5-1-5, Kashiwanoha, Kashiwa 277-8561
}

・トルク出力がエンジンよりも2桁ほども早く，空転防 止制御が適用できる。

・出力トルクを電流から容易に知ることができるので, 路面状態推定を行うことができる。

- 基本的に加速と減速に違いがないため, 従来の PWM 油圧ブレーキ制御に比べて滑らかで高性能なブレーキ 制御が可能となる。

・電気モータは小型軽量であるため各輪に分散配置し, 駆動力差によって車体姿勢制御が適用できる。

これらの電気モータの特性を生かして, これまでに EV におけるスリップ抑制制御や路面状態推定法, ダイレクト ヨーモーメント制御法が提案されている(1)(2)。

$\langle\mathbf{1} \cdot \mathbf{2}\rangle$ 本研究の背景と目的 RSC は乗り心地だけで なく, 車高の高いトラックやSUV などの安全性に対して も非常に重要である。NHTSAによれば, 全事故における ロールオーバの事故は 3\%であるにも関わらず，致死率は 全事故の 33\%を占める ${ }^{(3)}$ 。電池を床面に敷き詰めて低重心 化が図られているとはいえ，エンジン車に比べ EVは比較 的小型で Static stability factor (SSF：車輪幅/車高）が小さ くなる傾向にある。また EV の場合操縦性も大きく変わっ てくるためYSC や RSC を含めたシャーシ技術は重要にな 
ると考えられる。

これまでに RSC システムは自動車メーカや部品メーカ等 で ABS システムを用いて研究開発が進められてきた ${ }^{(4)(5)}$ 。 一般的な RSC システムは急激な横加速度やロール角度の 発生に応じて, 油圧ブレーキ力を用いて各輪独立に制御を 行う。しかしブレーキアクチュエータ制御は PWM (Pulse Width Modulation）制御であり，精確なトルクを出力する ことも把握することも難しい。

エンジン車で行われてきた RSC だが，インホイールモー 夕搭載 EV の場合には両回転方向卜ルク出力でき, またモー 夕電流を計測することによって精確なトルク出力が把握可 能となる。

アクチュエータの利点に加え, 提案する RSC は外乱オブ ザーバ (DOB) をベースとした, 目標值追従性能と外乱抑圧 性能という二つの制御性能を独立に設計可能な二自由度制 御を適用している。近年ヨーレートやピッチング制御，ま たパワーステアリングの制御において二自由度制御が提案 されており，自動車制御分野で多くの適用例が報告されて いる(6)(7)。本論文では，まずステアリング操舵角と車速から 計算される目標值に対する追従性と, 横からの突風等の外 乱に対するロバスト性という二つの性能が二自由度制御に よって同時に実現されることを示す。さらに，ロールオー バの危険度を表すロールオーバ指標 $(R I)$ を用いて RSC た けでなく，ヨー運動も考慮した統合制御（ISP）についても 提案する。

\section{2. ロール安定化制御}

筆者らは以前にロールレートを用いた RSC を提案して いた ${ }^{(8)}$ 。しかし，ロールレートはロール角度の微分值であ り高周波ノイズや，ロール運動過渡期には信号が表れるも のの一定横加速度で旋回中などの定常状態には信号が取り 出せないことから, 望むような性能が得られなかった。そ こで, 今回ロールダイナミクスの時間遅れを考慮してロー ル角度ではなく，横加速度を用いたロール安定化制御系を 設計した。

〈2·1〉横加速度外乱オブザーバ＼cjkstart制御系で目標值応 答と外乱応答は二つの重要な特性であり, 独立に設計可能 である。PID 制御を代表とする 1 自由度制御系では目標值 と実際值の差を取ったところで大きな情報が久落し両者は 独立に設計できない。この場合，外乱応答を改善するには フィードバック $(\mathrm{FB})$ ゲインを大きくするしかないが， シ ステムが不安定になるばかりか, 指令值への追従性も悪く なってしまう。そこで，外乱抑圧と指令值追従性を別々に 設計できるDOB をべースとした二自由度制御を RSCへ適 用した。

Fig. 1 に横加速度 DOB のブロック線図を表す。提案する DOB は車体速度 $V$, 前輪ステアリング角度 $\delta$, 駆動力差 $N$ 及び横加速度 $a_{y}$ を使って, 外部環境からの横加速度外乱を 推定する。

Fig. 1 をもとにして横加速度指令值 $u, \delta$ 及び横加速度外

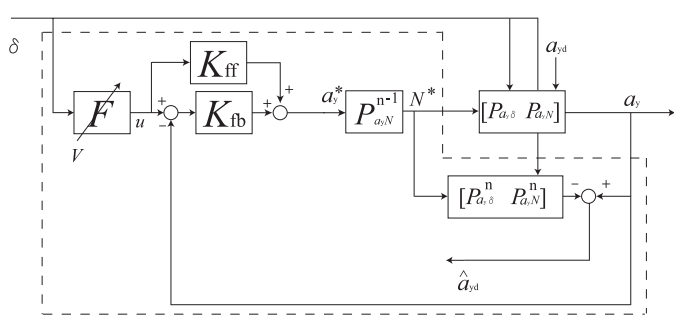

Fig. 1. Lateral acceleration DOB

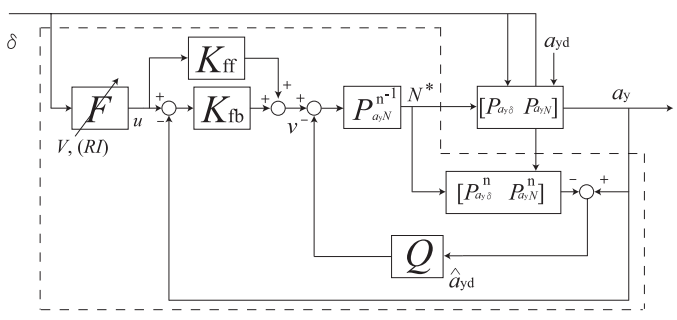

Fig. 2. 2-DOF for RSC based on DOB

乱 $a_{y d}$ から $a_{y}$ への伝達関数は以下で表わされる。ここで 横加速度指令值は前輪操舵角と車体速度 $V$ から与えられ, ロールモーメントは左右インホイールモータの駆動力差 $N^{*}$ で与えられる。

$$
\begin{aligned}
a_{y}= & \frac{\frac{P_{a_{y} N}}{P_{a_{y} N}^{n}}\left(K_{f f}+K_{f b}\right)}{1+\frac{P_{a_{y} N}}{P_{a_{y} N}^{n}} K_{f b}} u+\frac{P_{a_{y} \delta}}{1+\frac{P_{a_{y} N}}{P_{a_{y} N}^{y}} K_{f b}} \delta \\
& +\frac{1}{1+\frac{P_{a_{y} N}}{P_{a_{y} N}^{n}} K_{f b}} a_{y d} . \cdots \ldots \ldots \ldots \ldots \ldots \ldots \ldots \ldots
\end{aligned}
$$

また推定横加速度外乱 $\hat{a}_{y d}$ と $a_{y}$ は以下のように記述さ れる。

$$
\begin{aligned}
& \hat{a}_{y d}=a_{y}-P_{a_{y} N}^{n} N^{*}-P_{a_{y} \delta}^{n} \delta, \\
& a_{y}=P_{a_{y} N} N^{*}+P_{a_{y} \delta} \delta+a_{y d} .
\end{aligned}
$$

(2), (3) 式から駆動力差指令值を消去すると, 外乱推定は,

$$
\hat{a}_{y d}=\frac{P_{a_{y} N}}{P_{a_{y} N}^{n}}\left(\left(\frac{P_{a_{y} N}^{n}}{P_{a_{y} N}}-1\right) a_{y}+\left(P_{a_{y} \delta}-P_{a_{y} \delta}^{n}\right) \delta+a_{y d}\right)
$$

となる。(4) 式で, 第一項と第二項はモデルエラーであり, 第三項は横加速度外乱である。モデルエラーが十分小さい ならば， $\hat{a}_{y d}$ は近似的に横加速度外乱に等しくなる。

$\langle\mathbf{2} \cdot \mathbf{2}\rangle$ 二自由度制御による外乱抑圧性能とモデル追従 性能 Fig. 2 は提案する二自由度制御を RSC へ適用し た場合のブロック線図を示す。推定された横加速度外乱は フィルタ $Q$ をかけられた上で, 横加速度指令值へとフィー ドバックされる。

$$
a_{y}^{*}=v-Q \hat{a}_{y d} \cdot
$$

ここで, フィルタ $Q$ はローパスフィルタであり, 本論文で はこのカットオッフ周波数は $63 \mathrm{rad} / \mathrm{s}$ である ${ }^{(9)}$ 。 


$$
Q=\frac{1}{(s \tau)+1}
$$

(5) 式に(2) 式を代入すると，次式が得られる。

$$
a_{y}=v+P_{a_{y} \delta}^{n} \delta+(1-Q) \hat{a}_{y d} .
$$

$Q$ 及び車両ダイナミクスのカットオフ周波数よりも低い 外乱はDOBによって抑圧される。外乱抑圧性能に加えて, (4) 式に示すようにモデルエラーも補償されるため, カット オフ周波数以下であれば車両挙動はノミナルダイナミクス に近いものとなる。

\section{RSC と YSC の統合制御}

本章では, RSC と YSC との協調制御 (ISP) の必要性と, ロールオーバの危険度を表したRIについて述べる。

$\langle\mathbf{3} \cdot \mathbf{1}\rangle$ 協調制御の必要性横加速度は, 横滑り角微

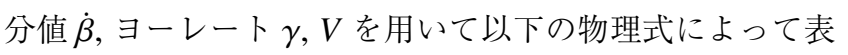
わされる。

$$
a_{y}=(\dot{\beta}+\gamma) V
$$

RSCによって横加速度が過度に抑えられてしまうと, 車 体速度が一定ならば, $\dot{\beta}$ を制御しない限り $\gamma$ も減少し, 運 転者にとって操縦しにくい車になってしまう。例えば低 $\mu$ 路では，タイヤで横力が発生できないために一般的にロー ルオーバの危険性よりもドリフトアウトの危険性の方が高 くなる。一方高 $\mu$ 路では, 夕イヤがグリップし速度によっ てはロールオーバする危険性がある。このように実際に適 用するには車体がどれだけロールオーバの危険性が高いか 検知し, その状態量に応じて車両を制御する必要と考えら れる。

そこでロールオーバの危険性を示す指標として RI を取 り上げる。これまでにもファジー制御を用いたロール状態 検知手法が提案されてきた ${ }^{(10)(11)}$ が，本論文では Yi らが提 案しているロールオーバ指標 $(R I)^{(12)}$ に，改良を加えた新 しい $R I$ を提案する。RI は車両ジオメトリとロールモデル の位相面解析をもとに, ロールオーバの危険性を 0-1 の大 きさで表わす指標である。前章で示した外乱にロバストな RSC を設計した上で，さらにこの指標を用いてロールオー バの状態に応じて駆動力差を制御する ISPを提案する。

本論文では制御入力として駆動力差しか用いていないた め, RSC と YSC の協調制御に適用するにあたって, 次の 3 通りの実現方法について考察した。

（1） RSC と YSC で横加速度とヨーレートを制御変数 として設定し, 最適問題として重みを $R I て ゙$ 可変とする。し かし RI は時変パラメータで, リアルタイムで FB ゲインに 関する方程式を解く必要がある。

（2） RSC と YSC の制御効果の割合を RI で決定する (可変重み $(\mathrm{VW})$ 型)。メリットとしては横加速度とヨー レート両方を制御できるものの，ゲインが時変となるため FB 制御設計には注意が必要となる。例えばワインドアップ を避けるために積分制御を用いないと定常誤差が残る。ま

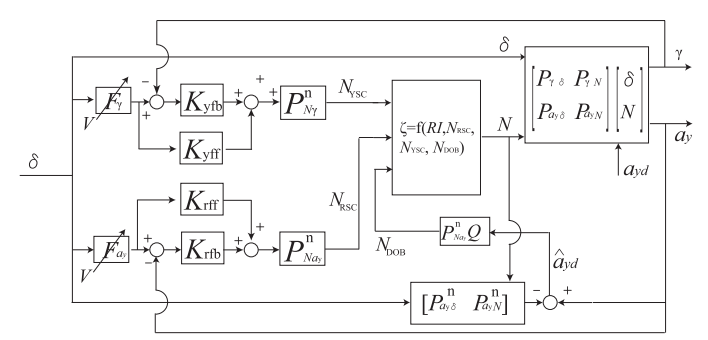

Fig. 3. Variable weight ISP

たゲインが変わるため特性方程式が代わり，指令值への収 束速度も変わる。

（3） RSC の指令值を RI の関数として用いる（可変指 令值（VR）型）。メリットとして積分制御が使えるため定 常誤差はなくなるが, YSCの効果は期待できなくなってし まう。

(1) は計算量の問題から適用が困難なので除外し, 本論 文では (2)と (3)について実験及びシミュレーションを行 い考察をした。

(2)の場合駆動力差指令值は, 各制御の出力である駆動 力差に RIで配分されたものと, ロールオーバの危険に関 わらず補償される DOB 分の駆動力差を引いたものとなる (Fig. 3)。

$$
\begin{aligned}
N^{*} & =f\left(R I, N_{R S C}, N_{Y S C}, N_{D O B}\right) \\
& =R I * N_{R S C}+(1-R I) * N_{Y S C}-N_{D O B}
\end{aligned}
$$

また ( 3 )の場合は Fig. 2 における指令值生成部分である $F に お い て$ 速度だけでなくRIの関数にする。

$$
u=(1-R I(1-\eta)) a_{y}^{*} .
$$

ここで $a_{y}^{*}$ は速度変化を考慮した横加速度のノミナル值, $\eta$ はノミナル值に対する RSC 適用時の横加速度の低減率で ある。RIが 0 の場合は横加速度の指令值とノミナル值は一 致し, RI が 1 の場合はそのまま低減率をかけられた值が指 令值となる。

〈3・2〉 ロールオーバ指標ＲIはゼロ次元でロールオー バの危険度を 0-1 で表した指標である。1に近いほど車両 のロール方向への運動が大きくロールオーバしやすいこと になる。

$R I$ を計算するにはロール状態量が必要となり, その中に はロール角度も含まれている。しかし, ジャイロセンサの 出力值はロールレートであり, これをそのまま積分しては 直流ドリフト成分のために発散してしまう。筆者らは，以 前にロールモデル同定 ${ }^{(8)}$ 及びロール角度推定 ${ }^{(13)}$ を提案し ているのでこれらについては割愛し，RIの計算法について 示す。

$R I$ は以下の 3 つのロール状態量によって決定される。

1. 現在のロール角度とロールレート

2. 現在の横加速度

3. time-to-wheel lift

である。Yiらの提案する $R I$ では，第 3 項の分母で次元の 


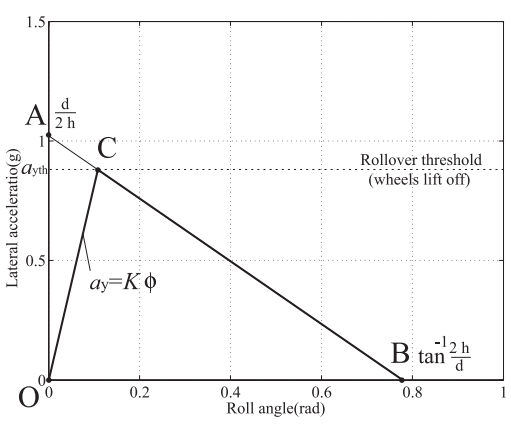

Fig. 4. Static roll dynamics of a suspended vehicle

異なるパラメータの和を用いていたため，それぞれ後述の 閾値で正規化したものに変更した。(11) 式に $R I$ の計算法 を示す。

$$
\begin{aligned}
R I= & C_{1}\left(\frac{|\phi| \dot{\phi}_{t h}+|\dot{\phi}| \phi_{t h}}{\phi_{t h} \dot{\phi}_{t h}}\right)+C_{2}\left(\frac{\left|a_{y}\right|}{a_{y t h}}\right) \\
& +\left(1-C_{1}-C_{2}\right)\left(\frac{|\phi| \phi_{t h} \dot{\phi}_{t h}}{\sqrt{\left(\phi \dot{\phi}_{t h}\right)^{2}+\left(\dot{\phi} \phi_{t h}\right)^{2}}}\right),
\end{aligned}
$$

if $\phi\left(\dot{\phi}-k_{1} \phi\right)>0$,

$$
R I=0 \text {, else if } \phi\left(\dot{\phi}-k_{1} \phi\right) \leq 0,
$$

ここで $\phi, \dot{\phi}$ はロール角度とロールレート， $C_{1}, C_{2}, k_{1}$ は 非負の定数である $\left(0<C_{1}, C_{2}<1\right)$ 。

$a_{y t h}$ は車両ジオメトリ（重心高，輪幅及びロール剛性の 関係）の静特性から決定される。Fig. 4 の線分 $\mathrm{AB}$ は, 懸 架車両を高さ $h$, 幅 $d$ の剛体と見なした時に，車両に加わ る横加速度と重力の平衡状態を示している。この線分の内 側では重力の影響の方が横加速度の影響よりも大きいため 車体はロールオーバしないが, 外側では横加速度の影響が 大きくなりロールオーバに至る。また線分 OC は車両に加 わる横加速度の影響とサスペンションが発生させる力の平 衡状態を示している。車体を剛体と見なした時，ロール角

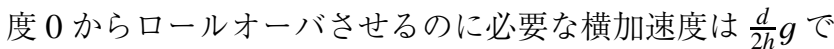
あるが，実際はサスペンションによってばね上が傾くため それよりも小さい横加速度でロールオーバに至る。従って この二つの直線の交点 Cが，車両ジオメトリ解析によって 導かれた横加速度閾值 $a_{y t h}$ となる。

次にこの $a_{y t h}$ とロールダイナミクスを用いてロール角度 とロールレートの閾値を決定する。Fig. 5 では，車体重心 に $a_{y t h}$ が加わった状態で様々な初期值からの $(\phi-\dot{\phi})$ 位相面 を描いている。赤い実線で示された領域はロール角度があ る角度点 $\mathrm{Q}$ に収束する安定領域となり，その外側の青い点 線で示された領域はロール角度が増加してロールオーバに 至る不安定領域となっている。車両がロールオーバするか しないかの限界領域に抢ける点 $\mathrm{P}$ と点 $\mathrm{Q}$ をそれぞれロール レート閾值 $\dot{\phi}_{t h}$, ロール角度閾值 $\phi_{t h}$ とした。

Fig. 6 に，例として $40 \mathrm{~km} / \mathrm{h}$ 一定速度走行中に 2 種類の 操舵角（30 度と 75 度に相当）を加えた場合の $R I$ 及び位相 面を示す。操舵角 75 度の場合はロールオーバするため $R I$

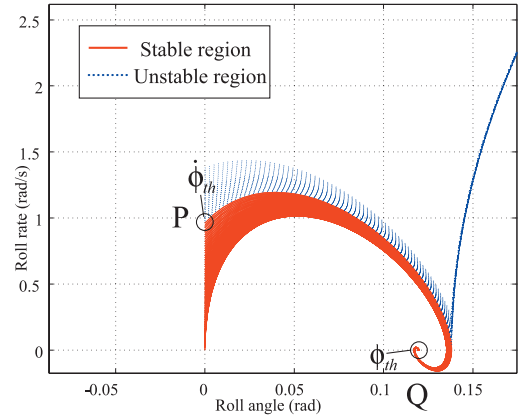

Fig. 5. Phase plane plot of roll dynamics
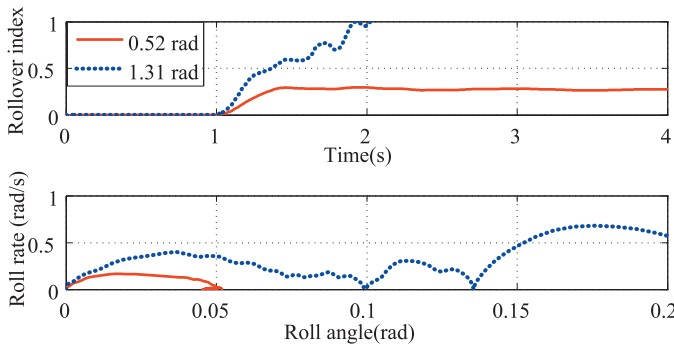

Fig. 6. $R I$ and phase plane depending on steering maneuver

は 1 となっており，ロールオーバの危険度を表しているこ とがわかる。

\section{4. シミュレーション結果}

CarSim7.11 と MATLAB R2006b/Simulink を組み合わ せた 3 次元車両運動モデルを用いて，シミュレーションを 行った。

まず，RSC の有効性を外乱抑圧と指令值追従性の観点か ら示す。実験に扔ける再現性の問題から外乱ロールモーメ ントは駆動力差で実現している。そして一定速度制御下に おいて直線走行と一定操舵角を加えている際に外乱を加え た。次に操舵角と車体速度から計算される指令值に横加速 度が追従することを，正弦波操舵シミュレーションによっ て確認した。

さらにISP の有効性を示すために，一定速度制御下でス テップ操舵角を加えている際の横加速度応答とヨーレート 応答及び軌跡を比較した。

\section{$\langle 4 \cdot 1\rangle$ RSC の実証}

$\langle\mathbf{4} \cdot 1 \cdot 1\rangle$ 横風外乱に対するロバスト性 $\mathrm{RSC}$ の横風 外乱に対する車両安定性をシミュレーションによって示す。 まず，車両は $20 \mathrm{~km} / \mathrm{h}$ 一定速度制御下で直線走行，操舵者 はステアリングホイールを $0 \mathrm{deg}$ で保持している時に，横 風が 3-6 sec 間に加えられた。Fig. 7 にその結果を示す。加 速度情報はノイズが大きいためLPF をかけている。

RSC 作動時には外乱ロールモーメントが駆動力差によっ て抑えられているのに対し, 非制御時には横風によって横 加速度が生じ，軌道も大きく外れてしまう。収束に時間が かかっているように見えるのは，外乱を駆動力差として入 力しているため夕イヤのダイナミクスによる時間遅れが加 


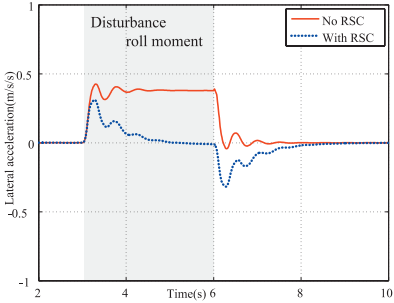

(a) Lateral acceleration

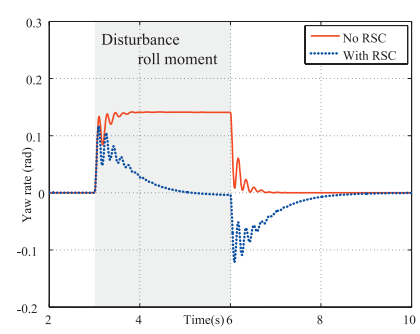

(b) Yaw rate
Fig. 7. Simulation result of RSC: Disturbance suppression at straight road drive

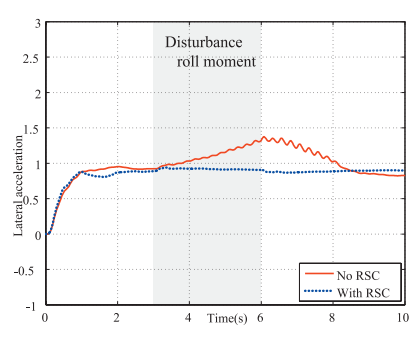

(a) Lateral acceleration

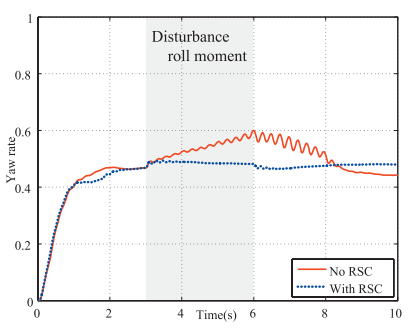

(b) Yaw rate
Fig. 8. Simulation result of RSC: Disturbance suppression at curving

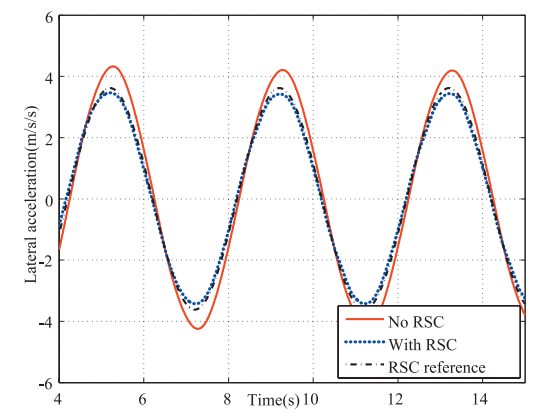

Fig. 9. Simulation result of RSC: Tracking capability to the reference value

わることと，横加速度にかけた LPF の影響であると考えら れる。

次に, 一定操舵角で旋回中に横加速度外乱が加えられた場 合について示す。同じく $20 \mathrm{~km} / \mathrm{h}$ 一定速度制御下で $180 \mathrm{deg}$ ステップ操舵を行ったあと，3-6 sec 間で外乱を加えた。 Fig. 8 に示すように RSC 作動時には駆動力差によって外 乱が打ち消されていることがわかる。これによってRSCの ロバスト性がシミュレーション結果によって示された。

$\langle\mathbf{4} \cdot \mathbf{1} \cdot \mathbf{2}\rangle$ 指令值追従性本章では RSC の指令值追従 性を示す。 $20 \mathrm{~km} / \mathrm{h}$ 一定速度制御下で振幅 $180 \mathrm{deg}$ の正弦 波操舵角を加えた。横加速度指令值はノミナル值の $80 \%$ と なるように設定されている $(\eta=0.8)$ 。Fig.9にRSC の横 加速度指令值への追従性を示す。非制御時に比べ，横加速 度が抑えられ，指令值に追従できていることが確認できた。

〈4・2〉 ISP の実証ＩSP の効果をシミュレーション によって検証する。ロールオーバの実験は安全上不可能な ので, 実験と比較するため安全な範囲での操舵シミュレー ションを行った。 $20 \mathrm{~km} / \mathrm{h}$ 一定速度制御下において $180 \mathrm{deg}$

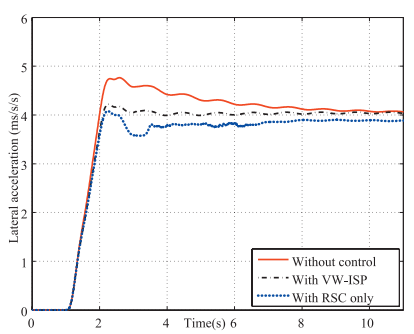

(a) Lateral acceleration

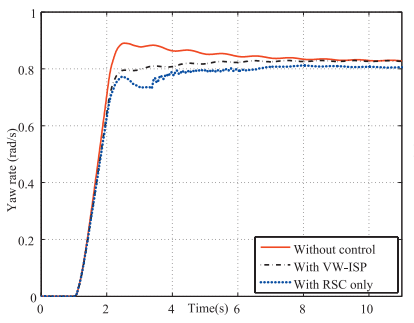

(c) Yaw rate

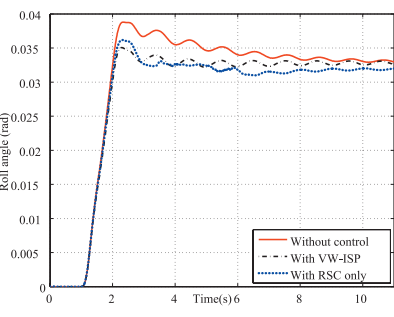

(b) Roll angle

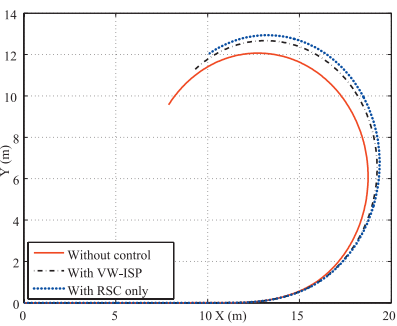

(d) Trajectory
Fig. 10. Simulation result of ISP (Var. weight): Step steering maneuver

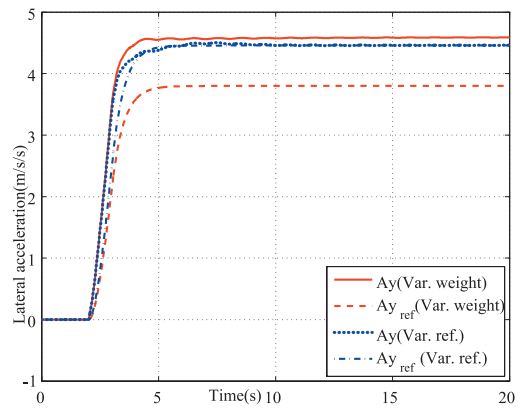

Fig. 11. Simulation result of ISP (var. weight and var. ref.): Step steering maneuver

ステップ操舵角を加えた。この検証では横加速度制御の効 果を見るために, 横加速度指令值はノミナル值の $80 \%$ と設 定し $(\eta=0.8)$ ，ヨーレート指令值はノミナル值を用いた。

$\langle\mathbf{4} \cdot \mathbf{2} \cdot \mathbf{1}\rangle$ 可変重み型 まず重みを $R I$ で可変とした VW 型 ISP について Fig. 10 にシミュレーション結果を示 す。RSC のみの場合過渡状態も定常状態でも横加速度は大 きく抑制され，軌跡が最も外側へふくらんでいることがわ かる。一方 ISP 作動時には過渡期ではロールレートととも にRI が大きくなるため横加速度が抑えられるものの, 定 常状態では RSC の効果が下がり YSC が作動するため横加 速度とヨーレートの抑制がともに緩和し非制御時に近い值 まで発生していることがわかる。シミュレーションによっ てVW 型 ISP の効果を確認できた。

$\langle\mathbf{4} \cdot \mathbf{2} \cdot \mathbf{2}\rangle$ 可变指令值型次に, 指令值に $R I$ を用いた VR 型 ISP について Fig. 11 にシミュレーション結果を示 す。条件はVW 型と同様であるが，RSC の FB ゲインに積 分制御を用いている。赤の実線が VW 型に対して, 青の点 線はVR 型を示している。VW 型の場合には定常誤差が発 生しているのに対して，VR 型の場合には積分制御によっ てほぼ誤差なく指令值に追従していることがわかる。従っ 
てVR 型 ISP の効果を示すことができた。

\section{5. 実験結果}

我々の研究グループは車両姿勢制御の実験検証を行うた めに，一人乗りの電動車両 “Capacitor COMS1”を開発し た。この車両は後二輪にインホイールモータを搭載し，ま た前輪操舵角センサ及び，ロール運動を検出するために加 速度/ジャイロセンサを搭載している。車両に搭載されてい る上位コンピュータによってセンサ情報が蓄積され駆動力

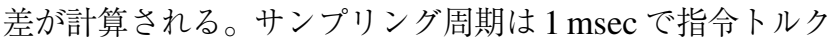
がインホイールモータに入力される。Fig. 12 に車両制御シ ステムを, Table 1 に実験車両の主要諸元を示す。

まず，RSC の有効性を外乱抑圧と指令值追従性の観点か ら示す。実験における再現性の問題から外乱ロールモーメ ントは駆動力差で実現した。そして一定速度制御下におい て直線走行と一定操舵角を加えている際に外乱を加えて制 御効果を検証した。次に操舵角と車体速度から計算される 指令值に横加速度が追従することを，正弦波操舵実験によっ て確認した。

さらにISP の有効性を示すために，一定速度制御下でス テップ操舵角を加えている際の横加速度応答とヨーレート 応答及び軌跡を比較した。

\section{$\langle\mathbf{5} \cdot \mathbf{1}\rangle$ RSC $の$ 実証}

$\langle\mathbf{5} \cdot \mathbf{1} \cdot \mathbf{1}\rangle$ 横風外乱に対するロバスト性 $20 \mathrm{~km} / \mathrm{h}$ 一定 速度制御下で 1 秒後に外乱を加えた。ただし加速度情報は ノイズが大きいためLPFをかけている。

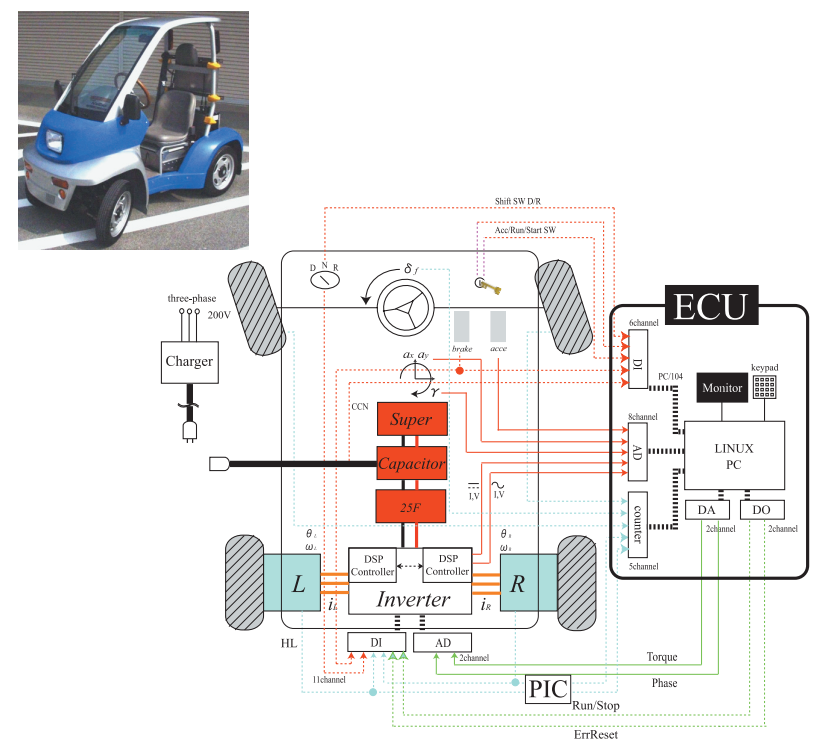

Fig. 12. Control system of experimental vehicle

Table 1. Drive train specification of experimental vehicle

\begin{tabular}{|c|c|}
\hline Category & IPMSM \\
\hline Phase $/$ Pole & $3 / 12$ \\
\hline Rating power/Max & $0.29 \mathrm{~kW} / 2 \mathrm{~kW}$ \\
\hline Max torque & $100 \mathrm{Nm}$ \\
\hline Max velocity & $50 \mathrm{~km} / \mathrm{h}$ \\
\hline
\end{tabular}

Fig. 13 に直線走行時の外乱抑圧性能を示す。ステップ上 の外乱ロールモーメント $\left(0.5 \mathrm{~m} / \mathrm{s}^{2} * h_{s}\right.$ に相当）が 1 秒後 に加えられているが非制御時及び RSC のフィードバック 制御のみ作動時には, 横加速度が抑えられずにヨーレート も発生していることが分かる。一方制御時には外乱を抑制 できていることが分かる。ここで横加速度外乱が打ち消さ れるまで達するまでに 1 秒前後かかっているのは, 夕イヤ のダイナミクスによるものである。車体に直接入るような 外乱に対してはもっと早く打ち消すことが可能である。

Fig. 14 はカーブ時（ステップステアリング操舵 240 度） において，4秒後に外乱を加えている時の実験結果である。 赤い実線は外乱が全くない状態での結果, 青い点線と緑の 一点鎖線は外乱が加えられた時を示している。シミュレー ションと同様に, 非制御時には外乱の影響を受けて横加速 度が 10\%程度下がってしまい, 不安定な挙動を示している のに対して，制御時には外乱がなかった時と同じように安 定した走行が可能となっている。ただしステアリング操舵 の再現性が難しかったため，デー夕はそれぞれの横加速度 の最大值でそれぞれの值を正規化している。

$\langle\mathbf{5} \cdot \mathbf{1} \cdot \mathbf{2}\rangle$ 指令值追従性 DOB の外乱抑圧性能が確認 できたので，指令值追従性を確かめるべく正弦波ステアリ ング操舵の実験を行った。指令值にはノミナル横加速度の $80 \%$ となるように調整した $(\eta=0.8)$ 。Fig. 15 は制御時と 非制御時の結果を示す。非制御時には大きな横加速度が出 て，車体も大きく振られていたのだが，制御時には横加速 度が指令值に追従していることがわかる。これでRSCの 指令值追従性能を示すことができた。

〈5・2〉ISP の実証ＩSP の効果を実験によって検証 する。安全上の理由からロールオーバさせることはできな

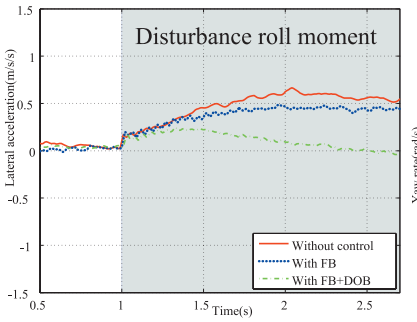

(a) Lateral acceleration

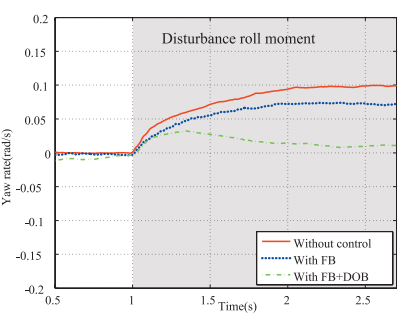

(b) Yaw rate
Fig. 13. Experimental result of RSC: Disturbance suppression at straight road drive

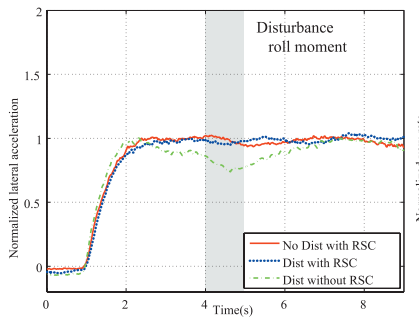

(a) Lateral acceleration

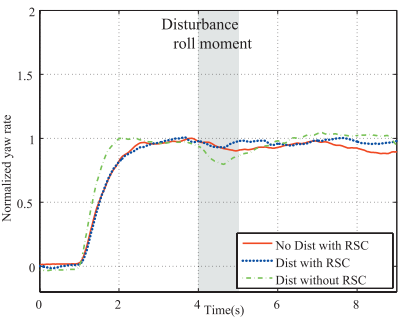

(b) Yaw rate
Fig. 14. Experimental result of RSC: Disturbance suppression at curve road driving 


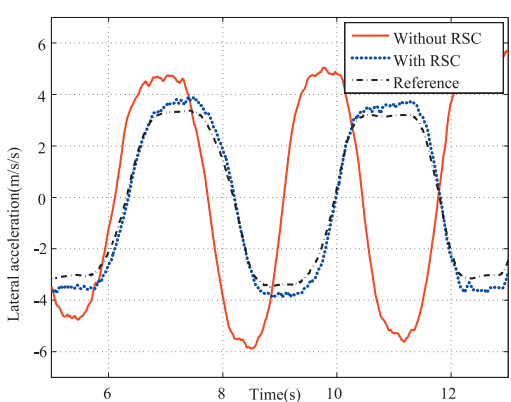

Fig. 15. Experimental result of RSC: tracking capability to the reference value

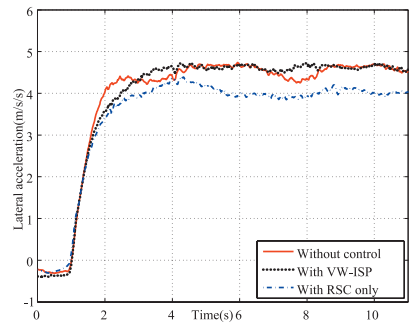

(a) Lateral acceleration

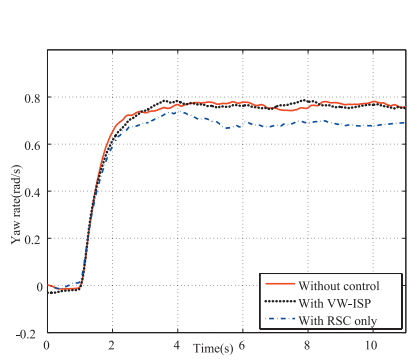

(c) Yaw rate

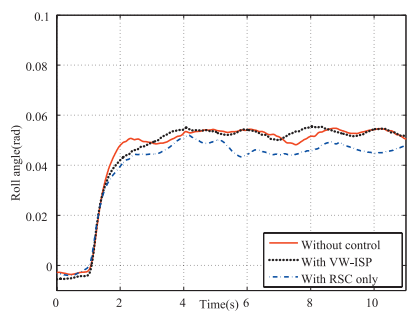

(b) Roll angle

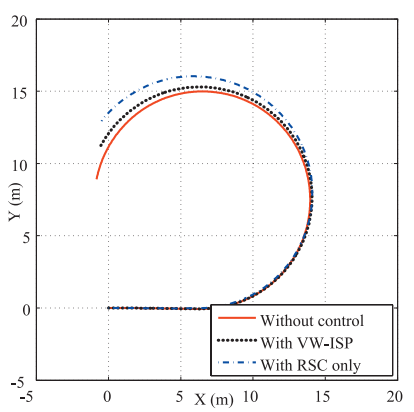

(d) Trajectory
Fig. 16. Experimental result of ISP (Var. weight): Step steering maneuver

いので〈4·2〉節のシミュレーションと同じ状況で，実験を 行った。 $20 \mathrm{~km} / \mathrm{h}$ 一定速度制御時に $180 \mathrm{deg}$ ステップ操舵 角を加えた。この検証では横加速度制御に関して RIでの 配分効果を示すことに重点をおいているため, 横加速度指 令值はノミナル值の $80 \%$ と設定し $(\eta=0.8)$, ヨーレート 指令值はノミナル值を用いた。

$\langle\mathbf{5 \cdot 2 \cdot 1 \rangle}$ 可変重み型まず重みを $R I$ で可変とした VW 型 ISP について Fig. 16 に実験結果を示す。まず非制御 時には, 横加速度の立ち上がりも早く, 定常值も約 $4.5 \mathrm{~m} / \mathrm{s}^{2}$ 程度となった。一方 RSCのみを行った場合, 過渡状態も 定常状態も横加速度はかなり抑えられていることが分かる。 さらに，VW 型 ISP 場合は過渡期はロールレートとともに $R I$ が大きくなるために横加速度の増加は抑えられるが，定 常状態ではYSC が作動したため横加速度もヨーレートも 非制御時と同程度となった。これによって VW 型 ISP の効 果を示すことができた。

$\langle\mathbf{5} \cdot \mathbf{2} \cdot \mathbf{2}\rangle$ 可変指令值型次に, 指令值に $R I$ を用いた VR 型 ISP について Fig. 17 に実験結果を示す。条件はVW 型と同様であるが，RSCの FB ゲインに積分制御を用いて

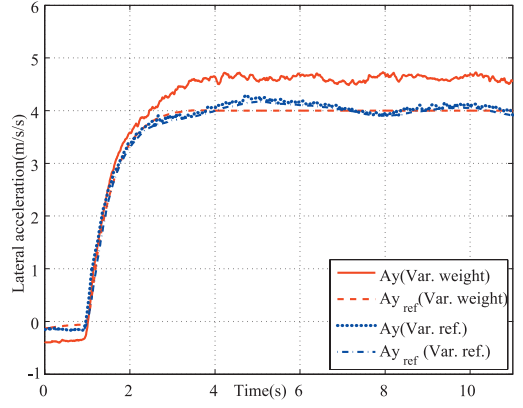

Fig. 17. Experimental result of ISP (var. weight and var. ref.): Step steering maneuver

いる。

赤の実線がVW 型に対して, 青の点線はVR型を示して いる。VW 型の際には YSC も作動させているため定常誤 差が発生しているのに対して, VR 型の場合には積分制御に よって誤差なく指令值に追従していることがわかる。従っ て VR 型 ISP の効果を示すことができた。

\section{6. おわりに}

本論文では，まず二自由度制御系で設計された RSC の外 乱抑圧性・モデル追従性と指令值追従性を実験結果で示し た。さらに駆動力差のみを制御入力とした場合に, ロール 状態とヨー運動を考慮したISPを提案した。ISP の実現法 として VW 型と VR 型の考察を行った。VW 型では, 一般 的にゲインを下げれば応答周波数も下がり, 定常誤差も表 れてしまう。一方 YSCをアクティブステアリング等の他 の制御入力と組み合わせて制御することを考えれば，VW 型に比べ特性方程式が変化せず定常誤差も低減できる VR 型の方が有効であることを示すことができた。

\section{謝 辞}

筆者と本研究成果は東京大学グローバル COE プログラ ム「セキュアライフエレクトロニクス」及び日本学術振興 会の援助を受けております。

(平成 21 年 8 月 10 日受付，平成 21 年 12 月 22 日再受付)

\section{文献}

(1) Y. Hori: "Future Vehicle driven by Electricity and Control-Research on Four Wheel Motored UOT Electric March II", IEEE Trans. Industrial Electronics, Vol.51, No.5, pp.954-962 (2004-10)

(2) H. Fujimoto, A. Tsumasaka, and T. Noguchi: "Vehicle Stability Control of Small Electric Vehicle on Snowy Road", JSAE Review of Automotive Engineers, Vol.27, No.2, pp.279-286 (2006-4)

(3) National highway traffic safety administration, Safercar, http://www.nhtsa.gov/

(4) E.K. Liebemann: "Safety and Performance Enhancement: The Bosch Electronic Stability Control (ESP)", SAE Technical Paper Series, 2004-21-0060 (2004-10)

(5) H.E. Tseng, et al: "Estimation of land vehicle roll and pitch angles", Vehicle System Dynamics, Vol.45, No.5, pp.433-443 (2007-5)

(6) S. Mammar: "Two-Degree-of-Freedom $H_{\infty}$ Optimization and Scheduling for Robust Vehicle Lateral Control", Vehicle Systems Dynamics, Vol.34, pp.401-422 (2000-12)

(7) B.A. Guvenc, T. Bunte, D. Odenthal, and L. Guvenc: "Robust Two Degreeof-Freedom Vehicle Steering Controller Design", IEEE Trans. Control Sys- 
tems Technology, Vol.12, No.4, pp.627-636 (2004-7)

(8) K. Kawashima, T. Uchida, and Y. Hori: "Rolling Stability Control of Inwheel Electric Vehicle Based on Two-Degree-of-Freedom Control", The 10th International Workshop on Advanced Motion Control, pp.751-756, Trento Italy (2008-3)

(9) T. Umeno and Y. Hori: "Robust Speed Control of DC Servomotors Using Modern Two Degrees-of-Freedom Controller Design", IEEE Trans. Industrial Electronics, Vol.38, No.5, pp.363-368 (1991-10)

(10) B.-C. Chen and H. Peng: "Differential-Braking-Based Rollover Prevention for Sport Utility Vehicles with Human-in-the-loop Evaluations", Vehicle System Dynamics, Vol.36, No.4-5, pp.359-389 (2001)

(11) A. Hac, et. al: "Detection of Vehicle Rollover", SAE Technical Paper Series, 2004-01-1757, SAE World Congress (2004)

(12) K. Yi, et al: "Unified Chassis Control for Rollover Prevention, Maneuverability and Lateral Stability", AVEC2008, pp.708-713 (2008-10)

（13） 河島清貴 • 内田利之・堀 洋一：「各輪垂直抗力情報を用いた車体動 的重心移動推定法」, 電学自動車研, VT-07-09, pp.51-56 (2007-4)

河 島 清 貴 (学生員) 2004 年 3 月, 東京大学工学部電気科

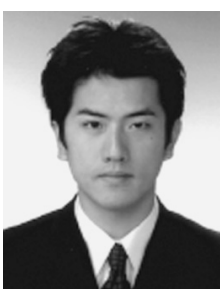
卒業。2006 年 3 月, 同大学大学院工学系研究科 電気工学専攻卒業。同大学院電気工学専攻博士課 程。主として電気自動車の運動制御に関する研究 に従事。
内田 利 之 (非会員) 東京大学工学系研究科電気系工学専攻 技術専門職員。実験装置の開発・改良を担当。最 近では，コンバート EV，キャパシ夕搭載車両，2

関節筋駆動ロボットアームを製作。

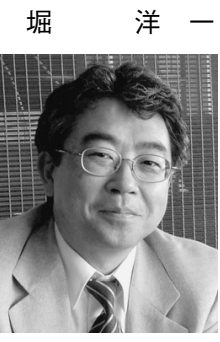

（上級会員） 1983 年 3 月, 東京大学大学院工学系 研究科電気工学専門課程博士課程修了。2000 年 同専攻教授。 2002 年 10 月東京大学生産技術研究 所教授, 2008 年 4 月より東京大学大学院新領域創 成科学研究科教授。専門は制御工学とその産業応 用，特にモーションコントロール，メカトロニク ス, 電気自動車などの分野への応用研究。現在, 電 気学会産業応用部門部門長。1993 年および 2001 年, IEEE Trans. on IE 最優秀論文賞, 2000 年電気学会論文賞などを受 賞。IEEE Fellow。その他, 計測自動制御学会, 日本ロボット学会, 日 本機械学会, 自動車技術会, 日本シミュレーション学会などの会員。 